Journal Universitas Muhammadiyah Gresik Engineering, Social Science, and Health International Conference (UMGESHIC)

UMGCINMATIC : $1^{\text {st }}$ Rethinking Education during Covid-19 Era: Challange and Innovation

\title{
RELATIONSHIP OF MOTIVATION TO THE LEVEL OF CONFIDENCE IN WORKING ON THE FINAL LEVEL STUDENT'S THESIS
}

\author{
AUTHOR \\ Okta Narita Putri Fartisia1, Nadhirotul Laily² \\ Universitas Muhammadiyah Gresik ${ }^{1}$, \\ Universitas Muhammadiyah Gresik ${ }^{2}$
}

\section{Email: putrifatrisia@gmail.com $\square$, nadhirotul.laily@umg.ac.id ${ }^{2}$}

\begin{abstract}
Self-confidence is a belief that a person has that he is able to behave as needed to get the expected results. Based on the results of interviews and observations of final year students, the results of this research phenomenon are related to the confidence of final year students. What is obtained from this research phenomenon is that students must have the drive to increase their self-confidence, because there are still students who are still afraid and don't want to ask questions about their final project because they are not confident and are still afraid of being wrong. The purpose of this study was to determine the relationship of motivation to the level of self-confidence in doing thesis for final year students. This research is a quantitative research. Subjects in this study amounted to 117 students. The selection of subjects in this study used a non-probability sampling technique with a purposive technique. Data collection techniques using questionnaires and using a Likert scale. Data analysis in this study using Product Moment correlation with the help of the SPSS program.
\end{abstract}

Keywords: Motivation, self-confidence, students

\section{INTRODUCTION}

The main priority that plays an important role for the development and progress of a nation is the field of education [1]. Education is the existence of a process in order to influence students to be able to adapt as best as possible to their environment which will cause changes in themselves that allow them to function adequately in people's lives from elementary school to college [2]. According to Bandura (Sudardjo and Purnamaningsih, [3], self-confidence is a belief that a person has that he or she is able to behave as needed to get the expected results. [3] states that people who are confident have a positive attitude towards themselves. Self- 


\section{UMGCINMATIC: $1^{\text {st }}$ Rethinking Education during Covid-19 Era: Challange and Innovation}

Volume 1 No 2

confidence is an important aspect of human personality as a means to actualize one's potential. Self-confidence is a person's mental attitude in assessing himself and the surrounding objects so that the person has confidence in himself to be able to do something according to his abilities. Individuals who have high self-confidence will look calmer, have no fear, and are able to show confidence at all times.

From the results of interviews conducted that this motivation is very necessary in working on the thesis, good motivation will provide a boost in good self-confidence in working on the thesis. every student is afraid to make mistakes in doing it [4], the thesis can be said to be the culmination of achievement, scientific proof, and even a means of a student's contribution to society. The process to be taken in working on the thesis is quite long, starting from determining the title/theme, making research proposals, seminars to conducting research. Selfconfidence affects individuals in viewing their abilities, especially in completing difficult tasks. Individuals who have confidence in their ability to complete academic tasks will not shy away from difficult tasks, and feel confident in being able to complete these tasks even though they tend to be [5]. Seeing the hopes of parents who want their children to graduate soon in carrying out this final project, it requires motivation to increase their self-confidence. Many students are still ashamed and believe that many of them are still afraid of making mistakes. People who have high self-confidence will show behavior that is comfortable for themselves, because they have no doubts about their abilities or doubts about the knowledge they have.

The problem regarding students' self-confidence needs to be taken seriously by lecturers in lectures. In the learning process the lecturer is the first party to interact directly with students in the class, so that they have an important role in raising students' self-confidence during the learning process. I, as a researcher, took the subject of this psychology student studying psychological theory which should be applied by psychology students themselves. But even though psychology students have studied it, it cannot be applied in everyday life, therefore I as a researcher take the subject of the psychology student.

\section{METHODS}

This type of research is quantitative. The data collection technique used in this research is to use a scale. The type of scale used in data collection in this study is the Likert scale. Respondents were asked to give their approval or disapproval on several questions consisting of two categories, namely favorable and unfavorable. This scale consists of four answer choices, namely Very Appropriate (SS), Appropriate (S), Not Appropriate (TS), and Very Disagree (STS). The population in this study were students majoring in psychology with a total of 117 students. The sampling technique used in this study is a purposive sampling technique, which is a sampling technique that uses the criteria that have been selected by the researcher in selecting the criteria sample if the sample is divided into inclusion and exclusion criteria. Inclusion criteria are the criteria for the sample that the research wants based on the research 
objectives. Meanwhile, the exclusion criteria are special criteria that cause prospective respondents who meet the inclusion criteria to be excluded from the research group.

The criteria in this study are as follows:

a. Psychology Student.

b. Currently Taking Thesis Course / Thesis Proposal .

c. Registered as an Active Student in the Psychology Study Program

d. Semester 5/7 Mahasiswa Student

To determine the accuracy and accuracy of a test measuring instrument in carrying out its measuring function. A test is said to have high validity if the measuring instrument performs the measuring function correctly or provides measurement results that are in accordance with the purpose of the measurement, meaning that the measurement results from these measurements are quantities that accurately reflect the facts or actual conditions of what is being measured. there are certain conditions to determine that the item can be valid, namely $r=0.3$. If the item is less than 0.3, it can be ascertained that the item is invalid [13].[14] explains that a reliability test will show the extent to which the accuracy or accuracy of the measuring instrument with measurement results is reliable and reliable. Reliability is an instrument which, when used several times to measure the same thing, will also obtain the same results as before or can be called measurement consistency. Reliability test using Cronbach's Alpha by using this test, the data is said to be reliable if the value of Alpha is more than 0.6 and if the Alpha value is less than 0.6 then the data can be said to be unreliable. In this test, Cronbach's Alpha coefficient formula is used. The reference in this study was used with the help of SPSS version 26. To prove the research hypothesis using the product moment correlation test for the validity or correctness of the data, we as researchers used the IBM statistical all program for social science program in SPSS version 26.0 Windows in the statistical analysis process.

\section{RESULT AND DISCUSSION}

\section{a. Confidence}

Self-confidence is the belief that someone is able to overcome a problem with the best situation and can provide something pleasant for others. It can be concluded that selfconfidence is the belief to do something about the subject's self as a personal characteristic in which there is confidence in one's own abilities, optimistic, objective, responsible, rational, and realistic.

\section{1) Aspects of Confidence}

Someone who has positive beliefs is as follows:

Self Confidence

Self-efficacy belief is a person's positive attitude about himself. He is truly capable of what he does.

\section{2) Optimistic}


Optimism is a positive attitude that is owned by someone who always has a good view in dealing with everything about himself and his abilities.

3) Objective

People who view problems or things according to the truth that should be, not according to personal truth or according to themselves.

4) Responsible

Responsibility is the willingness of people to bear everything that has become a consequence.

5) Rational And Realistic

Analysis of a problem, thing, and event by using thoughts that are acceptable to reason and in accordance with reality.

\section{6) Factors Affecting Confidence}

The factors that affect self-confidence in each individual, [10] namely:

\section{Family environment}

Family is the first and foremost environment in life the life of every human being, the educational environment in the family is very affect the initial formation of one's selfconfidence (Purnamaningsih, 2003).

\section{formal education}

School is the second environment for children, where school is the environment that plays the most role for children after the family environment at home. (Adywibowo, 2010) Schools provide space for children to express their confidence in their peers.

\section{non-formal education.}

One of the main capital to be able to become someone with a good personalityselfconfidence is having certain advantages that are meaningful to oneself and others. Ability or skills in certain fields can be obtained. through non-formal education such as taking courses in foreign languages, journalism, vocal arts, skills to enter the world of work, and so on.

\section{b. Motivation}

Motivation is defined as a force, drive, need, enthusiasm, pressure, or psychological mechanism that encourages a person or group of people to achieve certain achievements in accordance with what is desired. Based on the opinion above, motivation can be interpreted as a person's strength (energy) that can cause a level of willingness to carry out an activity. Willingness comes from within the individual itself (intrinsic motivation) and from outside the individual (extrinsic motivation). How strong the motivation of the individual will largely determine the quality of the behavior he displays.

\section{1) Motivational Aspects}


According to Maslow there is a hierarchy of needs Maslow. Aspects of motivation based on the hierarchy of needs:

\section{Physiological needs}

The most basic, strongest, and most obvious of all human needs is the need for physical survival. Maslow argued that the behaviorist belief that physiological needs have a major influence on human behavior can only be justified insofar as these needs are not satisfied.

\section{Safety Needs}

The need for security, as related to the need for security of life and the need for security of property. In Maslow's view, the need for security has been felt by the individual since childhood when he was exploring his environment.

\section{Belongingness And Love Needs}

The need for love and belonging, to be owned. Maslow said that we all need to feel wanted and accepted by others. Some satisfy this need through friendship, family, or organization.

\section{Esteem Needs}

The need for esteem, the fulfillment of this need leads to self-confidence and a sense of self-worth. The need for esteem is often filled with frustration and personal conflict because what people want is not only attention and recognition from their group, but also honor and status that requires moral, social, and ethical standards. religion.

\section{Self-Actualization Needs}

This need arises in a person if other needs are met because the need for selfactualization, like other needs, becomes increasingly important. This type of need is the most important aspect of human behavior. Maslow described this need as the desire to be fully self-sufficient, to be whatever one is capable of.

\section{Factors Affecting Motivation}

Factors that influence [13] there are five factors that influence motivation, namely:

\section{Needs}

The process of motivation because of a need or a sense of lack of something. 
Individuals who have needs will be motivated to move their behavior to satisfy these needs.

\section{Attitude}

An individual's attitude towards an object will involve emotions (feelings of pleasure or displeasure), directing or avoiding the object and a cognitive target, namely how the individual imagines or perceives something.

\section{Interest}

Interest will bring special attention to an object and will lead to motivation.

\section{Mark}

Value is an individual's view of something or a goal or what is considered important in his life.

\section{Aspiration}

This aspiration is an individual's expectation of something, and the individual will try to achieve the things that are expected.

\section{c. The Relationship between Motivation and Confidence Level}

From the theory above, the researcher concludes that motivation can affect selfconfidence in doing thesis, students who have high confidence and motivation will increase their confidence in doing thesis and finish immediately so that they can graduate on time.

Good motivation allows each individual to work better in his group. Good appearance must be shown by the existence of good motivation and skills so as to enable their goals to be achieved. A person must have a strong motivation in working on a thesis, a strong motivation something difficult becomes easy to do, something heavy becomes light to implement, meaning that with high motivation something impossible becomes possible.

based on the description of the relationship between the variables above, the conceptual framework of this research is as follows:

\section{MOTIVATION:}

A. Physiological needs

B. Safety Needs

C. Belongingness And Love

\section{CONFIDENCE}

1. Self concept

2. Pride

3. Experience 


\section{Figure 1. Conceptual framework}

\section{Based on the conceptual framework above, there are hypotheses in this study:}

1. Ha : There is a relationship between motivation and the level of self-confidence in doing thesis for final year students

2. Ho: there is no relationship between motivation and level of self-confidence in doing thesis for final year students

\section{CONCLUSION}

This study aims to determine the relationship between motivation and self-confidence in doing thesis in final year students. The research method uses a quantitative approach. The research respondents are final year students who are taking their thesis. The results of the research and discussion will be explained after the research is carried out.

\section{REFERENCES}

Tisngati, Urip, Nely Indra Meifiani. 2014. "The Influence of Self-Confidence and Parenting Patterns in Number Theory Courses on Learning Achievement". Journal of Derivatives Volume 1 No. 2

Mayangsari, Marina Dwi. 2013. "Student Achievement Motivation Judging From Parental Acceptance". Journal of Social Sciences, Vol. 5, No. 2

Fenti, Muhammad Sudia, Kadir. 2020. "The Effect of Learning Motivation and Level of Confidence on Mathematics Learning Outcomes". Vol. 1, No. 1

Amelia, Bella, Veny Elita, Yulia Irvani Dewi. 2015. "The Relationship of Parenting Parenting with Motivation to Continuing Education to Higher Education for Teenagers in the Riau Coastal Area". JOM Vol 2 No 2

Afriyana, Siti Zulfa, Mulyati, Hamiyati. 2020. The Relationship of Assertiveness and Motivation with Time Management Skills in Compiling Student Thesis. Journal of Family Welfare and Education. Vol 7, number 1, pp. 74-86 
Friday. Veny Elita, Fath FatwatI, Annisa Mentari, Fuadah Fakhruddiana. "The Tendency of Permissive Parenting and Confidence with Achievement Motivation in Students". HUMANITAS Vol. 11-1.9-18

Annis Nauli. 2015. "The Relationship Between Parenting Patterns With Adolescent Confidence In Kulim Village". Journal of Nursing Widya Gantari Vo. 2 No.2

Nur Ghufron, Rini Risnawati, Psychological Theories, (Jakarta : AR-RUZZ MEDIA, 2017)

Judge, Thursan. 2002. Overcoming Distrust. Yogyakarta: Torren Boo

Suprihatin, Siti. 2015. Teachers' Efforts in Improving Student Learning Motivation. Vol.3.No.1

Rivaldi, Alvin, Daryati, and Rosmawita. 2020. Factors Affecting the Motivation of Building Engineering Education Students To Become Teachers. Journal of Civil Engineering Education (Jpensil) Volume 9, No. January 12020

Basuki, Introduction to Quantitative Research Methods, (Indonesia: Media Sains Indonesia, 2021)

Pinton Setya Mustafa, Hafidz Gusdiyanto, Andif Victoria, et al, Quantitative, Qualitative, and Classroom Action Research Methodology in Sports Education, (Faculty of Sports Science, State University of Malang, 2020)

Dominikus Dolet Unaradjan, Quantitative Research Methods, (Jakarta: Atma Jaya Unika Publisher Jakarta, 2019)

Muslich Ansori, Quantitative Research Methods Edition 2, (Airlangga University Press, 2020) Hikmayanti Huwaida, Descriptive Statistics, (POLIBAN PRESS, 2019)

Sya'ban, H. (2006). Writing a thesis is just a formality?Pikiran Rakyat.www.mindedrakyat.com/print/2006/012006/19/kampus/utama02.htm

Chernis, C. \& Goleman, D. (2001). The emotionally intelligent workplace. San Francisco: Jossey Bass a Willey Company.

Schiffman, LG, \& Kanuk, LL (2007). Consumer behavior 8th edition. New Jersey:Pearson Education

Azwar, S. (2014). Preparation of the Psychological Scale. Yogyakarta: Student Library

Azwar, S. (2017). Psychological Research Methods. Yogyakarta: Learning Library

Sari, Indah Permata, Frischa Meivilona Yendi. 2018. The Role of Counselors in Increasing the Confidence of Students with Physical Disabilities

Cheseda Makaria, Eklys, Ali Rachman, Ririanti Rachmayanie. 2019. Correlation of SelfConfidence and Academic Self-Efficacy of Guidance and Counseling Study Program Students Class 2018. Indonesian Counseling Journal. Vol. 5 No. 1.

Fitri, Emria Nilma Zola, Ifdil Ifdil. 2018.Adolescent Self Confidence Profile and Influencing Factors. Indonesian Journal of Educational Research. Volume 4 Number 1.

Ghozali, Imam. 2013. Application of Multivariate Analysis with IBM SPSS Program Azwar, S. 2011. Reliability and Validity. Yogyakarta: Pustaka Pelajar Tina Aflatin den Sri Mulyanl Martanlah. 1998.Increasing Adolescent Confidence Through 
Group Counseling. Psychology. Number 6.

Sugiyono. (2016). Research Methods Quantitative, Qualitative and R\&D. Bandung PT Alfabet. Apriansyah Beni, Sulaiman \& Siti Baitul Mukarromah.2017.Contribution of Motivation, Cooperation, Confidence to the Achievement of Athletes at the Pati Football School Training Center in Pati Regency. Journal of Physical Education and Sports. Vol 6.Number 2.

Matondang Zulkifli. 2009. Validity and Reliability of a Research Instrument. Journal of Tabularasa Pps Unimed. Vol.6 No.

Alex Sobur, General Psychology in Historical Trajectory, (Bandung: CV PUSTAKA SETIA, 2003), 274-280

Eriany Praharesti, Lucia Hernawati, Haryo Goeritno. 2014. Descriptive Study of Factors Affecting Motivation to Participate in Activities. Psychomensia. Vol. 13 No. 1

Amelia, Bella, Veny Elita, Yulia Irvani Dewi. 2015. "The Relationship of Parenting Parenting with Motivation to Continuing Education to Higher Education for Teenagers in the Riau Coastal Area". JOM Vol 2 No 2.

Urip Tisngati, Nely Indra Meifiani. 2014. "The Influence of Self-Confidence and Parenting Patterns in Number Theory Courses on Learning Achievement". Journal of Derivatives Volume 1 No. 2

Tisngati, Urip, Nely Indra Meifiani. 2014. "INFLUENCE OF CONFIDENCE AND PARENTING PATTERNS IN NUMBER THEORY COURSE ON LEARNING ACHIEVEMENT". Journal of Derivatives Volume 1 No. 2 Pg 68

Tisngati, Urip, , Nely Indra Meifiani. 2014. "INFLUENCE OF CONFIDENCE AND PARENTING PATTERNS IN NUMBER THEORY COURSE ON LEARNING ACHIEVEMENT". Journal of Derivatives Volume 1 No. 2 Pg 69

Sya'ban, H. (2006). Writing a thesis is just a formality?Pikiran Rakyat.www.mindedrakyat.com/print/2006/012006/19/kampus/utama02.htm

Cheseda Makaria, Eklys, Ali Rachman, Ririanti Rachmayanie. 2019. Correlation of SelfConfidence and Academic Self-Efficacy of Guidance and Counseling Study Program Students Class 2018. Indonesian Counseling Journal. Vol. 5 No. 1.

Kholidin, FI 2018. The Effectiveness of Using Guided Imagery Techniques to Increase Confidence in High School Students. Thesis. Malang: Postgraduate Program, State University of Malang.

Lestari, Tri., Nahadi., Elis Solihati. 2021. Role Playing for Optimizing Student Confidence in Early Childhood Education Teacher Candidates. Volume 16 Number 1June 2021

Nur Ghufron, Rini Risnawati, Psychological Theories, (Jakarta : AR-RUZZ MEDIA, 2017)

Nur Ghufron, Rini Risnawati, Psychological Theories, (Jakarta : AR-RUZZ MEDIA, 2017)

Tri Nur Fadhila, Diana Endah handayani. Rofian. 2019. Analysis of Parenting Patterns on Student Learning Motivation. Vol 2 No 2, Year 2019 
Alex Sobur, General Psychology in Historical Trajectory, (Bandung: CV PUSTAKA SETIA, 2003), pp:274-280

Eriany Praharesti, Lucia Hernawati, Haryo Goeritno.2014. Descriptive Study of Factors Affecting Motivation to Participate in Activities. Psychomensia. Vol. 13 No. 1

Azwar, S.(2019). Preparation of the Psychological Scale: second edition. Yogyakarta: Learning Library

Sugiyono. (2016). Research Methods Quantitative, Qualitative and R\&D. Bandung PT Alfabet. 